九州大学学術情報リポジトリ

Kyushu University Institutional Repository

\title{
Manganobarian Muscovite from the Manganese Deposit of the Muramatsu Mine, Nagasaki Prefecture, Japan
}

Hirowatari, Fumitoshi

Faculty of Sciences, Kyushu University

https://doi. org/10.5109/1524297

出版情報：九州大學理學部紀要：Series D, Geology. 5 (4)，pp.191-198，1957-01-31. 九州大学理学 部 バージョン：

権利関係 : 


\title{
Manganobarian Muscovite from the Manganese Deposit of the Muramatsu Mine, Nagasaki Prefecture, Japan*
}

\author{
By
}

\section{Fumitoshi HIROWATARI}

\begin{abstract}
Manganobarian muscovite, recently found in the manganese deposit of the Muramatsu mine, occurs in a braunite-rich manganese ore as a small veinlet, or as a coating on drusy cavities.

It is rose-pink to light pink in colour, while under the microscope, practically colourless. $\mathrm{n}_{\mathrm{X}}=1.566, \mathrm{n}_{\mathrm{Y}}=1.598, \mathrm{n}_{\mathrm{Z}}=1.602, \mathrm{n}_{\mathrm{Z}}-\mathrm{n}_{\mathrm{X}}=0.036 ;(-) 2 \mathrm{~V}=36^{\circ}$, op. pl. $\perp 010$ The chemical formula is

$\left(\mathrm{K}_{0.53} \mathrm{Na}_{0.25} \mathrm{Ba}_{0.11} \mathrm{Ca}_{0.09}\right)_{0.98}\left(\mathrm{Al}_{1.48} \mathrm{Fe}_{0.10} \mathrm{Mn}_{0.20} \mathrm{Mg}_{0.28}\right)_{2.04}\left(\mathrm{Si}_{3.02} \mathrm{Al}_{0.98}\right)_{4.00} \mathrm{O}_{10.00}(\mathrm{OH})_{2.00}$

The $\mathrm{x}$-ray powder data confirm that polymorphic modification of this mineral agrees closely with that of the common 2-layer monoclinic structure proposed by HENDRICKS and JEFFE $a_{0}=5.25 \pm 0.02 \mathrm{~A}, b_{0}=9.10 \pm 0.02 \mathrm{~A}, c_{0}=19.90 \pm 0.03 \mathrm{~A}, \beta=95^{\circ} 40^{\prime}$. Using these values, most of lattice spacings have been indexed. Thus, this mineral belongs to a mica of the muscovite type (heptaphyllite), with the 2-layer monoclinic structure (common or normal muscovite structure). But it differs from the common muscovite in containing unusually high amounts of barium and manganese.
\end{abstract}

\section{Occurrence}

The manganese ore deposits of the Muramatsu mine**, about 10 kilometers north-west of Nagasaki City, Kyushu, are composed of lenticular ore bodies in the crystalline schist together with red-sericite-quartz schist and piedmontite-quartz schist both forming the wall rocks of the ore deposit.

The ores consist mainly of fine-grained braunite crystals, usually associated with beautiful rods of piedmontite and are cut by small veinlets of quartz and feldspar. The manganobarian muscovite in question, which was found by me in December of 1954, occurs in the braunite ore as a small veinlet or as a coating on drusy

* Read at the meeting of The Mineralogical Society of Japan on Oct. 23, 1955.

* According to Yosnimuka's genetical classification of manganese deposits in Japan (1952, 1953), the Muramatsu mine is the type locality of his "Muramatsu type"- the regionally metamorphosed manganese deposit. 
cavities. Pink spherulitic aggregates made up of tiny scales of this mineral offer a splendid specimen.

\section{Optical properties}

Megascopically the mineral, hexagonal plates about $0.5 \mathrm{~mm}$ to $0.1 \mathrm{~mm}$ in diameter, is rose-pink to light pink in colour, vitreous in luster, while under the microscope it is practically colourless.

Optical data are:

The optic plane and $Z$ are normal to $010 . \mathrm{n}_{\mathrm{X}}=1.566, \mathrm{n}_{\mathrm{Y}}=1.598, \mathrm{n}_{\mathrm{Z}}=1.602$, $\mathrm{n}_{\mathrm{z}}-\mathrm{n}_{\mathrm{X}}=0.036,(-) 2 \mathrm{~V}=36^{\circ}$ (obs.), (-) $2 \mathrm{~V}=35^{\circ}$ (calc.)

\section{Chemical composition}

The material used for chemical analysis contained no more than one per cent impurities. K. MUTA kindly examined the material spectrographically with the results that substantial amounts of $\mathrm{Mg}, \mathrm{Ba}, \mathrm{Mn}, \mathrm{Ti}$ and $\mathrm{Fe}$ were determined, but $\mathrm{V}$, $\mathrm{Cr}, \mathrm{Li}$, Co were not detected.

The results of my chemical analysis are given in Table 1, No. 1. Manganese determination was checked by the gravimetric and volumetric methods, whose results are in satisfactory agreement. The barium was precipitated with sulphuric acid and was weighed as $\mathrm{BaSO}_{4}$. The water was determined by calcium chloride method.

The formula for the muscovite in question calculated from its chemical composition on the basis of $\mathrm{O}_{10}(\mathrm{OH})_{2}=22$ is :

$$
\left(\mathrm{K}_{0.53} \mathrm{Na}_{0.25} \mathrm{Ba}_{0.11} \mathrm{Ca}_{0.09}\right)_{0.98}\left(\mathrm{Al}_{1.48} \mathrm{Fe}_{0.10} \mathrm{Mn}_{0.20} \mathrm{Mg}_{0.26}\right)_{2.04}\left(\mathrm{Si}_{3.02} \mathrm{Al}_{0.98}\right)_{4.00} \mathrm{O}_{10.00}(\mathrm{OH})_{2.00}
$$

Thus, it is evident that the mineral closely approaches the accepted theoretical formula for muscovite, namely $\mathrm{X}_{1} \mathrm{Y}_{2} \mathrm{Z}_{4} \mathrm{O}_{10}(\mathrm{OH})_{2}$, where $\mathrm{X}$ are $\mathrm{K}, \mathrm{Na}, \mathrm{Ba}$, and $\mathrm{Ca}$; $\mathrm{Y}$ are $\mathrm{Al}, \mathrm{Fe}, \mathrm{Mn}$, and $\mathrm{Mg} ; \mathrm{Z}$ are $\mathrm{Si}$ and $\mathrm{Al}$.

\section{Thermal properties}

A part of the sample used for the chemical analysis were examined by a differential thermal analysis method. The result is shown in Fig. 1. The D.T.A. curve

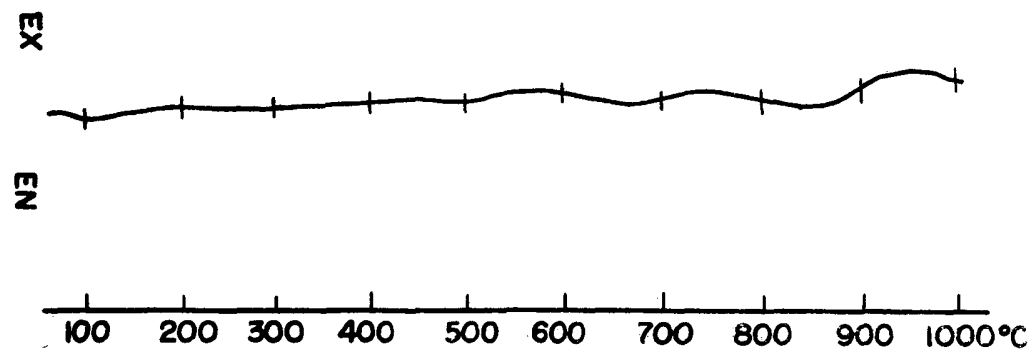

Fig. 1. Differential thermal analysis curve for manganobarian muscovite from the Muramatsu mine. 
Table 1. Chemical analyses of manganobarian muscovite, muscovites and lepidolite

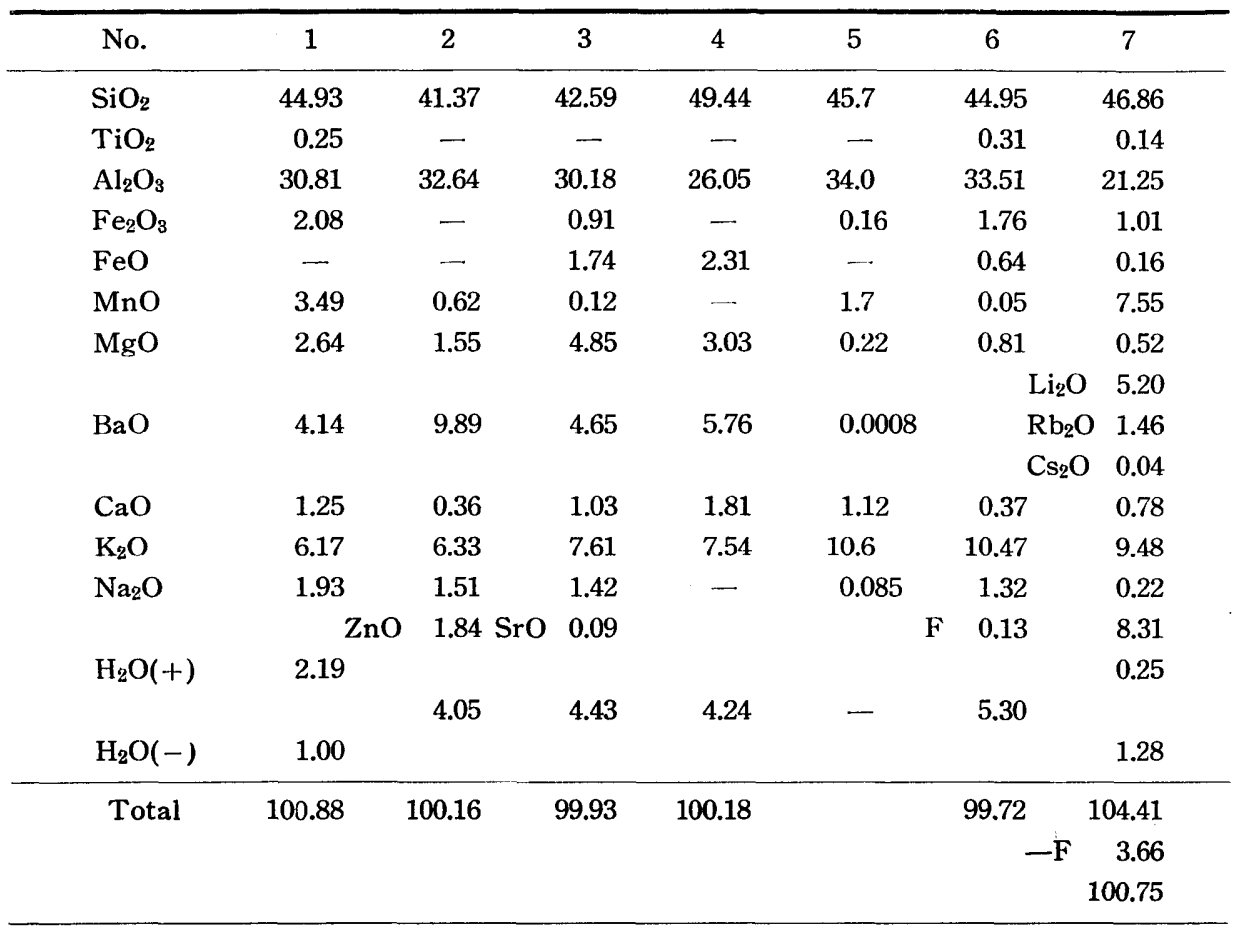

(1). Manganobarian muscovite, Muramatsu mine, Nagasaki, Japan.

Analyst: F. Hirowatari (this paper).

(2). Barium-muscovite, Franklin Furnace, New Jersey.

Analyst: L. H. BaUER (1933).

(3). Oellacherite, Ptitschthal, Tyrol.

Analyst: F. Oellacher (1858).

(4). Oellacherite, Habachtal, Tyrol.

Analyst: F. Bergman (1875).

(5). Mangan-muscovite, Mattkärr, Finland.

Spectrochemical analysis by C. E. HARveY (1955).

(6). Muscovite (average of 37 specimens), calculated by

K. Rankama and Th. G. Sahama (1950).

(7). “Lepidolite," Sakihama, Iwate, Japan.

Analyst: H. Shibata (1952).

shows two endothermic peaks, though indistinct, one at about $670^{\circ} \sim 700^{\circ} \mathrm{C}$ and the other $800^{\circ} \mathrm{C} \sim 900^{\circ} \mathrm{C}$.

\section{X-ray powder data and identification of polymorphism}

The powder diffraction data for $\mathrm{CuK}_{\alpha}(\lambda=1.5418 \mathrm{~A})$ radiations were obtained, using a camera with $114.6 \mathrm{~mm}$ in diameter. The measured and calculated lattice spacings together with the visually estimated intensities are given in Table 2, Column 1, comparing with the data for normal muscovite from Chandlers Holler (Column 2; NAgelschmidT, 1937) and lithian muscovite from South Portland (Column 3; Levinson, 1953) 
Table 2. X-ray powder data for manganobarian muscovite, normal muscovite and lithian muscovite

\begin{tabular}{|c|c|c|c|c|c|c|c|c|}
\hline \multirow[b]{2}{*}{ hkl } & \multicolumn{3}{|c|}{$\begin{array}{c}\text { Manganobarian muscovite, } \\
\text { Muramatsu mine }\end{array}$} & \multicolumn{3}{|c|}{$\begin{array}{l}\text { Normal muscovite, } \\
\text { Chandler Holler }\end{array}$} & \multicolumn{2}{|c|}{$\begin{array}{l}\text { Lithian mus- } \\
\text { covite, S.P. }\end{array}$} \\
\hline & $\mathrm{d}(\mathrm{A})_{\text {calc }}$ & $\mathrm{d}(\mathrm{A})_{\text {obs. }}$ & $I^{*}$ & $\mathrm{~d}(\mathrm{KX})_{\text {calc. }}$ & $\mathrm{d}(\mathrm{KX})_{\text {obs. }}$ & $I^{*}$ & $\mathrm{~d}(\mathrm{~A})_{\text {obs. }}$ & $I^{*}$ \\
\hline 002 & 9.92 & 9.93 & $\mathrm{~m}$ & 9.95 & 9.98 & s & 9.95 & $\mathrm{~m}$ \\
\hline 004 & 4.96 & 4.97 & $\mathrm{~m}$ & 4.97 & 5.00 & s & 5.01 & $\mathrm{~m}$ \\
\hline$\left\{\begin{array}{l}020 \\
110\end{array}\right\}$ & $\left\{\begin{array}{l}4.55 \\
4.53\end{array}\right\}$ & 4.51 & $\mathrm{~m}$ & $\left\{\begin{array}{l}4.50 \\
4.48\end{array}\right\}$ & 4.49 & $\mathrm{~s}$ & 4.50 & $\mathrm{~m}$ \\
\hline 112 & 4.01 & & & & & & 3.95 & vvw \\
\hline $11 \overline{3}$ & 3.89 & 3.91 & w & 3.86 & 3.91 & $\mathbf{w}$ & 3.87 & vvw \\
\hline 023 & 3.75 & 3.70 & w & 3.72 & 3.73 & w & 3.71 & $\mathrm{w}$ \\
\hline $11 \overline{4}$ & 3.49 & 3.50 & $\mathbf{w}$ & 3.48 & 3.50 & $\mathrm{~m}$ & 3.46 & w \\
\hline 024 & 3.36 & 3.38 & $\mathbf{w}$ & 3.35 & & & & \\
\hline 006 & 3.32 & 3.31 & vs & 3.31 & 3.33 & vs & 3.32 & $\mathrm{~ms}$ \\
\hline 114 & 3.22 & 3.19 & w & 3.20 & 3.20 & $\mathrm{~m}$ & 3.21 & $\mathrm{~m}$ \\
\hline 025 & 2.99 & 2.98 & $\mathrm{~m}$ & 2.98 & 3.00 & $\mathrm{~m}$ & 2.98 & $\mathrm{~m}$ \\
\hline 115 & 2.88 & 2.84 & $\mathrm{~ms}$ & 2.86 & 2.88 & $\mathrm{~m}$ & 2.84 & $\mathbf{s}$ \\
\hline $11 \overline{6}$ & 2.77 & 2.77 & $\mathrm{w}$ & 2.779 & 2.80 & $\mathrm{~m}$ & 2.755 & $\mathrm{w}$ \\
\hline$(131)$ & $2.587)$ & & & 2.568 & & & & \\
\hline$\{20 \overline{2}\}$ & $2.585\}$ & 2.59 & $\mathrm{msB}$ & 2.566 & 2.57 & vs & 2.571 & $\mathrm{~ms}$ \\
\hline$(116)$ & 2.583) & & & $2.565)$ & & & & \\
\hline$(008)$ & 2.481 & & & 2.485 & & & & \\
\hline $13 \overline{3}\}$ & $2.477\}$ & 2.48 & wB & & 2.475 & wB & 2.474 & $\mathrm{~m}$ \\
\hline (202) & $(2.476)$ & & & & & & & \\
\hline$\left\{{ }^{133}\right\}$ & $2.404\}$ & 2.390 & wB & 2.380 & 2.385 & $\mathrm{~m}$ & 2.387 & $\mathrm{~m}$ \\
\hline$\{20 \overline{4}\}$ & $\mid 2.402\}$ & 2.020 & WD & $\{2.382\}$ & 4.000 & 111 & 2.004 & II \\
\hline$(134)$ & 2.279 & & & & & & & \\
\hline 205 & 2.278 & & & & & & & \\
\hline 040$\}$ & $2.275\}$ & 2.264 & vwB & 2.270 & 2.28 & w & 2.247 & vw \\
\hline $22 \overline{1}$ & 2.268 & & & & & & & \\
\hline 041 & $(2.265)$ & & & & & & & \\
\hline$\left\{\begin{array}{l}22 \overline{3} \\
028\end{array}\right\}$ & $\left\{\begin{array}{l}2.202 \\
2.181\end{array}\right\}$ & 2.194 & vw & 2180 & 2.19 & $\mathbf{w}$ & 2.196 & vvw \\
\hline 043 & $2.152)$ & & & 2.100 & & & & \\
\hline 135$\}$ & 2.147 & 2.139 & wB & & 2.134 & s & 2.132 & $\mathrm{mw}$ \\
\hline $20 \overline{6})$ & $(2.145)$ & & & 2.142 & & & & \\
\hline$\{13 \overrightarrow{\mathbf{6}}\}$ & 2.105 & & & & & & & \\
\hline$\{223\}$ & $2.096\}$ & & & & & & 2.081 & $\mathrm{~m}$ \\
\hline$(136)$ & 2.010 & & & & & & & \\
\hline 029 & $1.987\}$ & 1.980 & vs & 1.986 & 1.995 & vs & & \\
\hline$(00,10)$ & $1.980)$ & & & 1.990 & & & & \\
\hline 206 & 1.951 & & & & & & 1.951 & vw \\
\hline 02,10 & 1.822 & 1.822 & vvw & 1.821 & & & & \\
\hline 208 & 1.728 & 1.729 & vvw & 1.714 & 1.730 & vw & 1.742 & w \\
\hline$\left\{\begin{array}{l}20, \overline{1} \overline{0} \\
00,12\end{array}\right\}$ & $\left\{\begin{array}{l}1.653 \\
1.650\end{array}\right\}$ & 1.643 & $\mathrm{mB}$ & & 1.651 & $s B$ & 1.644 & $\mathrm{~m}$ \\
\hline
\end{tabular}




\begin{tabular}{|c|c|c|c|c|c|c|c|c|}
\hline$(13, \overline{1} \overline{0})$ & $1.612)$ & & & & & & & \\
\hline$\{228\}$ & $1.615\}$ & 1.601 & vvw & & & & & \\
\hline 049 & $1.610)$ & & & & & & 1.596 & vvw \\
\hline 13,10 & 1.552 & & & 1.550 & 1.546 & vw & 1.557 & vvw \\
\hline 315 & I.525 & & & 1.531 & 1.523 & vw & & \\
\hline S & 1.512 ) & & & $(1.500)$ & & & 1.510 & vvw \\
\hline$\{33 \overline{1}\}$ & $1.515\}$ & 1.517 & $\mathrm{mB}$ & $\{1.499\}$ & 1.500 & $\mathbf{s}$ & 1.500 & $\mathbf{w}$ \\
\hline 063 & 1.478 & 1.480 & vvw & 1.463 & & & 1.487 & $\mathbf{w}$ \\
\hline 333$)$ & $1.450)$ & & & & & & & \\
\hline 064 & $1.450\}$ & 1.449 & vvwB & 1.440 & 1.450 & vw & 1.453 & vvw \\
\hline $\mid 33 \overline{5})$ & 1.449) & & & & & & & \\
\hline$(00,14)$ & $1.421)$ & & & 1.428 & & & & \\
\hline 334 & 1.416 & 1418 & yyw & & 1.421 & VW & 1.427 & vw \\
\hline $33 \overline{6}$ & 1.416 & & $V \nabla W D$ & & & & & \\
\hline$(065)$ & $1.415)$ & & & & & & & \\
\hline $31 . \overline{1} \overline{0}$ & 1.356 & 1.347 & w & 1.355 & 1.356 & $\mathrm{~m}$ & & \\
\hline$\{067\}$ & 1.338 & 1.337 & w & & 1.337 & $\mathrm{~m}$ & 1.340 & $\mathbf{w}$ \\
\hline$\{336\}$ & 1.337 ' & 1.038 & $\mathrm{w}$ & & & & & \\
\hline$\{260\}$ & 1.312 & 1.318 & vvw & & & & & \\
\hline$\{40 \overline{2}\}$ & $1.312\}$ & & & 1.298 & & & & \\
\hline 400 & 1.307 & & & & & & & \\
\hline 068 & 1.295 & & & & & & & \\
\hline $40 \overline{3}$ & 1.304 & & & 1.293 & & & & \\
\hline 401 & 1.297 & 1.302 & vwB & 1.283 & 1.296 & $\mathrm{~m}$ & 1.296 & vvw \\
\hline 337 & 1.294 & & & & & & & \\
\hline $33 \overrightarrow{9}$ & 1.293 & & & & & & & \\
\hline
\end{tabular}

* vs : very strong, $\mathrm{s}$ : strong, $\mathrm{ms}$ : middle strong, $\mathrm{m}$ : middle, $\mathrm{mw}$ : middle weak, $\mathrm{w}$ : weak, $\quad \mathrm{vw}$ : very weak, vvw: very very weak, $\mathrm{B}$ : broad line.

Polymorphism of the micas was first pointed out by Hendricks and JEFFERson (1939), who also stated that the muscovite type micas usually crystallize with the 2-layer monoclinic structure (2M polymorphs). However, further $\mathrm{x}$-ray studies of polymorphism in the mica group made by Axelrod \& Grimaldi (1949), Makenzie et al. (1949), Levinson (1953, 1955), HeINRICh \& Levinson (1955), and SMrTh \& Yorder (1954) tell us that the micas of the muscovite type crystallize not only with the $2 \mathrm{M}$ polymorphs, but also with five polymorphs, such as $6 \mathrm{M}, 3 \mathrm{H}, 3 \mathrm{~T}, 1 \mathrm{M}$, and $1 \mathrm{Md}^{*}$.

All of these polymorphic modifications were determined by the Weissenberg method. Grim and BradLey (1951) presented a paper on the method of distinguishing the polymorphic forms in the micas. They state: "In all of the mica powder diffraction diagram the region of clearest import is the range from about $4.4 \mathrm{KX}$ to $2.6 \mathrm{KX}$ which includes only $02 l$ and $11 l$ reflections." Supposing this suggestion to be used as the basis for the identification of polymorphism, I examined several

* 6M : 6-layer monoclinic structure. 3H : 3-layer hexagonal structure. 3T : 3-layer trigonal structure. 1M: 1-layer monoclinic structure. 1Md : 1-layer disordered monoclinic structure. 
$\mathrm{X}$-ray powder data for the muscovite type micas from various localities and found that $6 \mathrm{M}, 3 \mathrm{H}, 3 \mathrm{~T}, 2 \mathrm{M}, 1 \mathrm{M}$, and $1 \mathrm{Md}$ polymorphs could be discriminated by this method.

Now, the above-mentioned $\mathrm{x}$-ray powder data for the Muramatsu muscovite was found to be in close agreement with normal muscovite of the $2 \mathrm{M}$ polymorphs distinguished from those of $6 \mathrm{M}, 3 \mathrm{H}, 3 \mathrm{~T}$, IM, and $1 \mathrm{Md}$ polymorphs. The most noticeable characteristics of the Muramatsu muscovite (2M polymorphs) as compared with the other polymorphs are as follow: the (023), (11 $\overline{4}),(114),(025)$, and (11 $\overline{6})$ reflections which respectively correspond to $\mathrm{d}=3.70 \pm 0.02 \mathrm{~A}, 3.50 \pm 0.02 \mathrm{~A}, 3.20 \pm 0.02 \mathrm{~A}, 2.98 \pm 0.02 \mathrm{~A}$ and $2.78 \pm 0.02 \mathrm{~A}$ are distinct, while the reflections corresponding to $\mathrm{d}=4.3 \mathrm{~A}, 4.1 \mathrm{~A}$, $3.60 \pm 0.02 \mathrm{~A}$ and $3.10 \pm 0.02 \mathrm{~A}$ are absent. Thus the muscovite in question has a 2 layer monoclinic structure with the monoclinic unit cell dimensions given below.

\section{Unit cell dimensions}

The $\mathrm{d}_{001}$ dimension was determined by using the $(008),(00,10)(00,12)$ and $(00,14)$ reflections. The $\mathrm{d}_{010}$ dimension was obtained by taking the (060) reflection for $\mathrm{d}=1.517 \mathrm{~A}$. The $\mathrm{d}_{100}$ dimension and $\beta$ were determined by using the (336), (335) and (33i) reflections. The results are summarized in Table 3.

Table 3. Unit cell dimensions of manganobarian muscovite from the Muramatsu mine

\begin{tabular}{|c|c|}
\hline $1=5.23 \pm 0.02 \mathrm{~A}$ & . $5.25 \pm 0.02 \mathrm{~A}$ \\
\hline $\mathrm{d}_{010}=9.10 \pm 0.02 \mathrm{~A}$ & . \\
\hline$d_{001}=19.80 \pm 0.03 A$ & .. $c_{0}=19.90 \pm 0.03 \mathrm{~A}$ \\
\hline$\beta=95^{\circ} 40^{\prime}$ & .. $\beta=95^{\circ} 40^{\prime}$ \\
\hline
\end{tabular}

The cell dimensions of the manganobarian muscovite from the Muramatsu mine, those of the normal muscovite from Chandler Holler, and those of the lithian mus covite from South Portland will be compared with each other in Table 4.

Table 4. Cell dimensions of the 2-layer monoclinic muscovites

\begin{tabular}{c|c|c|c}
\hline & Manganobarian muscovite & Normal muscovite & Lithian muscovite \\
\hline $\mathrm{a}_{0}$ & $5.25 \pm 0.02 \mathrm{~A}$ & $5.2 \mathrm{KX}$ & $5.2 \mathrm{~A}$ \\
$\mathrm{~b}_{0}$ & $9.10 \pm 0.02 \mathrm{~A}$ & $9.0 \mathrm{KX}$ & $9.0 \mathrm{~A}$ \\
$\mathrm{c}_{0}$ & $19.90 \pm 0.03 \mathrm{~A}$ & $20.0 \mathrm{KX}$ & $20.0 \mathrm{~A}$ \\
$\beta$ & $95^{\circ} 40^{\prime}$ & $95^{\circ} 30^{\prime}$ & $95^{\circ} 30^{\prime}$ \\
\hline Author & HIROwATARI & HENDRICKs \& JEFFERSON & LEVINSON \\
& (this paper) & $(1939)$ & (1953) \\
\hline
\end{tabular}

Using the cell dimensions, most of lattice spacings were calculated and indexed with results given in Table 2 . 


\section{Nomenclature}

Muscovite with substantial amount of barium (BaO 4-5\%) from Ptitschthal, Tyrol, has been called “oellacherite" by DANA (1914, p. 614). Afterwards, a micaceous mineral with $8.89 \% \mathrm{BaO}$ from Franklin Furnace, New Jersey, was called "bariummuscovite" by BAUER and BERMAN (1933).

On the other hand, a lepidolite containing very high amount of manganese (MnO 7.55\%; Table 1, No. 7) has been reported from the Sakihama-pegmatite, Japan (Shibata, 1952). Recently a mangan-muscovite has been found from the Mattkärr, Finland (Hein Rich and Levinson, 1955), but this mineral contains only $1.7 \% \mathrm{MnO}$ (Table 1, No. 5).

Chemically, the muscovite from the Muramatsu mine shows similarities to "oellacherite" or barium-muscovite with respect to the high $\mathrm{BaO}$ content on one hand, and to mangan-muscovite on the other.

Structurally, both barium-muscovite and mangan-muscovite have the 1-layer monoclinic structure, while the Muramatsu muscovite and oellacherite the normal 2-layer monoclinic structure, though HEINRICH \& Levinson (1955a) put forth the opinion that the barium-muscovite can not be considered as a variety of normal muscovite.

The Muramatsu muscovite, chemically one kind of barium-muscovite and structurally of normal muscovite, may be called either "manganobarian muscovite" as a variety of normal muscovite or "manganoan oellacherite" as a variety of oellacherite. In this connection the noteworthy view of HEINRICH \& Levinson (1955a) should be taken into account that "the oellacherite from the type locality (Ptitschtal, Tyrol) has crystallized with the 2-layer monoclinic structure, but a flame test for Ba negative results and, therefore, the validity of this specimen is in doubt."

Therefore, I wish to propose a name "manganobarian muscovite" as a new variety of normal muscovite for the mineral from the Muramatsu mine.

\section{Acknowledgments}

I wish to express my sincere thanks to Professors T. Tomita and T. Yoshimura for their guidance and critical reading of this paper in manuscript. I also wish to thank Assistant Professor H. SHirozu and my colleague in our Department for their kind advices. Further, I am indebted to K. MUTA, Department of Economic Geology, Kyushu University, for his assistance in spectrographic analysis. 


\section{References}

Axelrod, J. M. and F. S. Grimaldi (1949). Muscovite with small optic axial angles. Am. Min., $34,559-572$.

Baver, L. H. and H. Berman (1933). Barium muscovite from Franklin, New Jersey. Am. Min., $18,30$.

DANA W. L. (1914). The system of mineralogy. New York, 6th Ed., 1134.

Grim, R. E. and W. F. Bradley (1915). The mica minerals: X-ray identification and crystal structure of clay minerals. London, 138-172.

Heinrich, E. WM. and A. A. Levinson (1955a). Studies in the mica group; X-ray data on roscoelite and barium muscovite. Am. Jour. Sci., 253, 39-43.

(1955b). Studies in the mica group: Polymorphism among high-silica sericites. Am. Min., 40, 983-995.

(1955c). Studies in the mica group; Mangan-muscovite from Mattkärr, Finland. Am. Min., 40, 1132-1135.

Hendricks, S. B. and M. E. Jefferson (1939). Polymorphism of the micas. Am. Min., 24, 729771.

Levinson, A. A. (1953). Studies in the mica group; Relationship between polymorphism and composition in the muscovite-lepidolite series. Am. Min., 38, 88-107.

(1955). Studies in the mica group; Polymorphism among illites and hydrous micas. Am. Min., 40, 41-49.

Makenzie, R. C., G. F. Walker, and R. HaRt (1949). Illite occurring in decomposed granite at Ballater, Aberdeenshire. Min. Mag., 28, 704-713.

Nagelschmidt, G. (1937). X-ray investigations on clays. Zeit. Krist., 97, 514-521.

Rankama, K. and Th. G. Sahama (1950). Geochemistry. The Univ. Chicago Press, 912.

Sudo, T. and K. Hayase (1950). On the chemical compositions of fine micas. Chm. Res., 8, 83-115 (in Japanese).

(1953). “Nendokobutsu" Iwanami-zensho, (in Japanese).

Sмith, J. V. and H. S. Yorder (1954). Theoretical and x-ray study of the mica polymorphs (abstract). Am. Min., 39, 343.

Shibata, H. (1952). Mineralization in granit-pegmatite in Japan and Korea. Parts II, III. Sci. Repts. Tokyo-Bunrica Daigaku, 2, 135 and 164.

Yoshimura, T. (1952). The manganese ore deposits in Japan. Mangan-kenkyukai, 567 (in Japanese).

(1953). Types of manganese deposits in Japan. Proc. 7th. Pac. Sci. Cong., 2, 216. 